Mette Louise Berg

University of Oxford

On the social ground beneath our feet: for a cosmopolitan anthropology

\title{
Abstract
}

This article argues that for a truly cosmopolitan anthropology to come about, we need to reflect critically on the conditions of our knowledge production. Using the example of women's under-representation within anthropology, and the marginalisation of the Caribbean, I argue that we need to think more about the social ground beneath our feet and recognise the differential access that anthropologists across the globe and at home have to the ongoing larger conversation that constitutes the discipline. We like to think that Universities are republics of letters in the Enlightenment spirit, in which free-flowing conversations take place between equals. Yet like other domains of knowledge production, academia is embedded in hierarchical structures imbued with power. We need to situate our ongoing conversation and our commitment to a cosmopolitan anthropology in this broader context. 


\section{On the social ground beneath our feet: for a cosmopolitan anthropology}

In an article entitled 'Culture, Identity and the Project of a Cosmopolitan Anthropology', published in 1994 Adam Kuper critiques post-modern and nativist anthropology for being too relativist and inward-looking. Rather than continuing on the 'culturological' track, Kuper argues for what he calls a cosmopolitan anthropology. For Kuper, this means an anthropology that would 'aspire to contribute a comparative dimension to the enlightenment project of a science of human variation in time and space'. He continues: 'Our object must be to confront the models current in the social sciences with the experiences and models of our subjects, while insisting that this would be a two-way process' with the ultimate aim of contributing to 'the larger conversation of the human or social sciences' (1994:551). Unfortunately, as Kahn has pointed out (2003), Kuper tells us very little about what he understands by cosmopolitanism and does not engage with any of the critiques that have been made of it.

In the decade and a half since the publication of Kuper's article, it has become clear that 'cosmopolitanism is back' (Harvey 2000:529). Like others, I followed Hannerz' suggestion that it has become time 'to let more ethnographers in' on the study of cosmopolitanism (2004:73). My engagement has accordingly taken the form of an ethnography of young diasporic Cubans living in Spain and the ways in which they use cosmopolitanism to construct subjectivities outside of constraining and reductive nationalist-territorial concepts of identity and Cubanness (Berg 2009). 'The children of the revolution', as I call this group, grew up in a world of actually existing socialist cosmopolitanism, which simultaneously was infused with commitment to a national, territorially-based political project: an independent, socialist Cuba. I have explored the ambiguous position of the children of the revolution vis-àvis exclusionary narratives of belonging in Spain, Cuba and among their exile compatriots Paradoxically, it was their upbringing to become the socialist New Man in revolutionary Cuba, which created the social and cultural capital that enabled them to embrace cosmopolitanism in order to break free from the national slot and carve alternative spaces of identification. I have emphasised that this carries considerable material consequences, such as the banning of individuals from travelling to Cuba even for family visits. In short, I have contextualised the cosmopolitanism of these diasporic children of the revolution materially, socially and historically, and sketched the complexity entailed in embracing cosmopolitanism for them. Other ethnographers have likewise traced the cosmopolitanism of subjects that until 
recently would not have been considered under that category. We can therefore now speak of various 'vernacular' or otherwise qualified 'countercosmopolitanisms' as Harvey has called them (2000:530). Thus while Kuper argued for a cosmopolitan anthropology, instead there has been a growth in anthropological studies of cosmopolitanism. While the two are related, they are not identical.

The debate on cosmopolitanism addresses several key issues of concern to anthropology and society at large, including the old debate of universalism versus relativism. In most of Europe and in the US, Canada and Australia, there have been intense public and scholarly debates over the virtues or shortcomings of multiculturalism in recent years (Vertovec and Wessendorf 2010). The interest in cosmopolitanism within and beyond anthropology is arguably linked to this debate. In this article however I want to address Kuper's question, namely that of the intellectual project of a cosmopolitan anthropology. Emphatically, this is not because I want us to turn our backs on the wider debate about cosmopolitanism and multiculturalism. Rather, I think we can improve our scholarly conversation by participating in it. I am thinking especially of the kind of critical sensibility that questions universalist projects, which has informed the new writing on cosmopolitanism.

Recent literature on cosmopolitanism spreads over a spectrum. At one end there are those, mostly political philosophers, who argue for a unified, universalist cosmopolitanism (e.g. Nussbaum 1994). Critics of this position have noted that notwithstanding the ideal, the paradigmatic cosmopolitan subject has tended to be male, Western and of the elite (not unlike the paradigmatic anthropologist). They have also critiqued the normativity and the focus on cosmopolitanism as a personal attribute, rather than as a social practice. As Noble has put it: 'practices may produce particular personality traits but it is the practices, not the attributes, which should be the point of a sociocultural analysis of cosmopolitanism' (2009:49). Werbner makes a similar point when she characterises cosmopolitanism as dialogical: 'a collective, creative endeavour, beyond the individual'. For her, anthropologists become cosmopolitan through engagement and conversation with other scholars (2008:25). In this spirit, I posit that we need to address the differential access that anthropologists across the globe and at home have to 'the larger conversation' of our discipline. We need to extend our ethnographic gaze to our own practices, not to 'retreat to a world of privacy' as Kuper disapprovingly puts it (1994:542), but as part of a necessary reflexive practice. As Bourdieu argues, reflexive analysis is 'opposed in every respect to a self-indulgent, intimist return to the singular, private person of the anthropologist'. It does however call into question the 
powerful 'charismatic representation that cultural producers have of themselves and their propensity to see themselves as free of all cultural determinations' (Bourdieu 2003:283; see also Calhoun 2003:532), a propensity shared with cosmopolitan liberals.

Kuper's notion of the cosmopolitan hinges upon his invocation of 'the larger conversation of the human or social sciences' (1994:551). Yet he leaves the conversation disembodied and abstract: Where does Kuper locate it? Who are the interlocutors? Is it conducted in English only? Who sets the agenda? Kuper does not address these questions, but one does get the impression that his cosmopolitan anthropology is a project that those of us fortunate enough to be based in wealthy institutions in the North have a rather better chance of accessing than others. Would we be content to delimit the conversation to the handful of prestigious Englishlanguage journals and international conferences that our colleagues in anthropology departments in the South have scant or no access to (see also Corsín Jiménez 2004; Gupta and Ferguson 1997)? Surely this would make it parochial rather than cosmopolitan.

In an interview conducted in 2000 Kuper acknowledges the problem and explains that his role in the founding of the EASA (European Association of Social Anthropologists) and this journal, was motivated by a desire to widen the conversation: 'My model is always that you've got to get more people in, you've got to get away from this closed, inward-looking, airless conversation which is so typical of disciplines on the slide - empty discourses' (Gibb and Mills 2001:214). I would add that recognising the inherently contested and political nature of the cosmopolitan, and its wider context, would seem important if we are to realise Kuper's ideal-type conversation. We like to think of academe as a republic of letters in the enlightenment spirit, in which free-flowing conversations take place between equals; the kind of conversation Kuper invokes. At this juncture, however, it may be sobering to remind ourselves of some demographic facts about anthropology, such as the gender composition of tenured academics (see also Mills and Berg forthcoming).

In the UK, women have dominated the undergraduate student body and the ranks of junior scholars for decades. Yet women have been seriously under-represented at senior level, even though individual female anthropologists like Mary Douglas and Marilyn Strathern have been among the most influential anthropologists in the late $20^{\text {th }}$ century.

Back in 1983, 82\% of anthropology teaching staff in UK universities were men (Riviere 1983). By 2001, this figure had reduced to around 55\%, except at the senior-most level, where three times more men than women held professorships (45 men; 15 women). Five 
years later, the overall gender balance at senior level remained unchanged. These figures are especially striking given that as early as in 1961 women outnumbered men among the youngest members of the Association of Social Anthropologists of the UK and Commonwealth (ASA) (Ardener and Ardener 1965:300). Since the ASA, then as now, only admits anthropologists who hold or have held a teaching or research position at a university, it would, all other things being equal, be reasonable to expect women to dominate the profession at all levels today. At the very least, these numbers raise troubling questions about who are enabled to contribute to our conversation and of the social basis for anthropology's cosmopolitanism. In short: who belongs? Could not a truly cosmopolitan anthropology as a minimum be expected to address the discipline's failure to enable its female students to participate in the conversation?

This article then is a critical reflection on the production of our disciplinary conversation and an attempt to outline why new critical understandings of cosmopolitanism are important for the project of a cosmopolitan anthropology. In short, I want to look at the social ground beneath our feet, the social conditions of our discourse. Just like fieldwork is no longer a black box out of which anthropological texts magically emerge, so the 'micropractices of the academy might well do with some scrutiny' (Rabinow 1986:253). Elsewhere, I have reflected, in collaboration with David Mills (forthcoming), on some of the reasons for the persistent gender inequalities within the discipline. In the remainder of this article, I discuss the marginalisation of the Caribbean from the disciplinary mainstream, in order to argue that a truly cosmopolitan anthropology needs to engage in a reflexive practice on its own knowledge production. ${ }^{1}$

\section{Cosmopolitan anthropology and the Caribbean}

The Caribbean has historically occupied an ambiguous place within anthropology. The history and heterogeneity of Caribbean societies, and their inescapable colonial nature, meant that anthropologists could not rely on the dominant tropes of pre-contact authenticity and purity of early and mid-twentieth century anthropology (Trouillot 1992:22). Put simply, most people in the Caribbean came from somewhere else and were therefore not considered suitable anthropological subjects. The Caribbean thus remained an ambiguous space for

\footnotetext{
${ }^{1}$ For similar discussions dealing with class and 'race' respectively, see Leach (1984), and Law et al. (2004).
} 
Western academia: not quite white enough for sociology, and not quite native enough for anthropology (Trouillot 1992:20). Furthermore, it was not geo-strategically important enough to merit funding from any major funding agencies, at least in the US (Gupta and Ferguson 1997:9). And so it remained a domain of regional specialists, often marginalised from the mainstream of the discipline (Trouillot 1992; Mintz 1996). Yet the very same features which meant that the region did not qualify as a suitable object of study in the past make Caribbean societies exemplary locations for studying key problematics of contemporary anthropology such as globalisation, migration, diasporic identities, transnationalism, creolisation, and not least cosmopolitanism (Mintz 1996; Wardle 2000).

One anthropologist who understood early the significance of the cultural processes in the Caribbean and who attempted to conceptualise them, was the Cuban Fernando Ortiz (18811969). Ortiz was born in colonial Cuba five years before slavery was abolished. He spent most of his childhood in Minorca, Spain and began his university studies in Barcelona. He went on to become a prolific public intellectual and essayist in Cuba whose scholarly work encompassed the fields of law, sociology, philology, ethnomusicology, politics, history, and anthropology. He started his trajectory as a criminologist on the premise of scientific racism, seeing Afrocuban culture as repugnant, primitive and savage. From this unpromising and unsavoury starting point, he later in life came to appreciate Afrocuban culture, and indeed pioneered scholarly interest in it. Any assessment of Ortiz and his work must grapple with this deeply problematic legacy, yet must also acknowledge the later Ortiz as a founder of Afro-Cubanism and an outspoken and radical critic of racism (Chomsky 2000:424-427).

Ortiz' major work Contrapunteo cubano del tabaco y el azúcar (Ortiz 1940), translated into English in 1947 as Cuban Counterpoint: Tobacco and Sugar, was an interpretation of Cuban history and culture through its two principal products. The first part of the book 'Cuban Counterpoint' is an allegorical tale of Cuban history contrasting tobacco and sugar counterpuntally. The second part, entitled 'The Ethnography and Transculturation of Havana Tobacco and the Beginnings of Sugar in America' is a more conventional historical essay. In the book, Ortiz introduced the word transculturation, which he hoped would replace the notion of acculturation, then the master concept within anthropology for understanding cultural contact and change. Ortiz argued that acculturation 'is used to describe the process of transition from one culture to another', whereas transculturation was meant to capture the 'extremely complex transmutations of culture', 'the problem of disadjustment and readjustment, of deculturation and acculturation' that have taken place in Cuba throughout 
the island's history (Ortiz 1995:98). The book is richly historical, allegorical and has literary qualities, and calls attention to 'the play of globally interconnected particularities' (Coronil 1995:xiv). It is an original work by 'a native anthropologist involved in the political struggles of his nation' (Coronil 1995:xxxv) in 'critical dialogue with metropolitan anthropology' (Coronil 2005:139). We could see the book as a cosmopolitan text in Beck's sense (2002), characterised as it is by a dialogic imagination and contrasting styles.

The first edition of Cuban Counterpoint was introduced by none other than Bronislaw Malinowski, then at Yale, who wrote that he had promised Ortiz to 'appropriate the new expression [i.e. transculturation] for my own use, acknowledging its paternity, and use it constantly and loyally whenever I had occasion to do so' (Malinowski 1995:lvii). For good measure, Malinowski also took the opportunity to call Ortiz a 'good functionalist' (Malinowski 1995:1xii), notwithstanding that Ortiz repeatedly distanced himself from functionalism, favouring instead an eclectic, historical approach (Coronil 1995:xxxv). Ortiz still welcomed the opportunity to have Malinowski introduce his book. After all, he wanted 'transculturation' to enter anthropological theory and it was not unreasonable to hope that an endorsement by a metropolitan scholar such as Malinowski would help his concept gain recognition (Coronil 1995:xxx). Yet as Coronil tersely notes, Malinowski subsequently used 'transculturation' only twice in his published works, and only on one of these occasions did he acknowledge Ortiz.

Ortiz' legacy continues to be recognised in Cuba today, not least through the Fundación Fernando Ortiz in Havana. Internationally, his scholarship undeniably received recognition at the time with the prompt appearance of an English edition of Cuban Counterpoint and an honorary doctorate from Columbia University in 1954. It is nonetheless telling that the Oxford English Dictionary now equates transculturation with acculturation, the very concept Ortiz hoped it would displace. It also credits Malinowski for introducing the word (Coronil 1995:xlv) ${ }^{2}$

This could have been the end of the story of a misrecognised scholar from the periphery whose contribution to metropolitan anthropology was forgotten in the Anglophone canon. But in the 1990s, after the fall of the Soviet Union when Cuba was reinserted into capitalist markets and its culture was marketed globally, Cuban music and cigars saw a revival; so did

\footnotetext{
${ }^{2}$ See

http://dictionary.oed.com/cgi/entry/50256130?single=1\&query type=word \&queryword=transculturation \&first= $1 \& \max$ to $s h o w=10$, consulted 06 April 2010.
} 
Ortiz' work. Cuban Counterpoint was re-issued by Duke University Press in 1995 with a new critical Introduction by the US-based Venezuelan anthropologist Fernando Coronil discussing the book, its reception, and its trajectory from a late twentieth century viewpoint. Ten years later, an English-language volume assessing Ortiz' legacy was published (Font and Quiroz 2005). The late Ortiz' transcultural, cosmopolitan, and counterpuntal contribution was taken up by postmodern scholars of literature and cultural studies (Pérez Firmat 1989; Benítez Rojo 1992). The disturbing racism in Ortiz' early writings remain troubling, and cannot be overlooked. Yet it does not seem implausible to explain Ortiz' near epistemological obliteration by Anglophone anthropology by his position as a peripheral, Caribbean scholar. Nor does it seem incidental that his legacy was rediscovered in a period of intensified globalization and at a time when Cuba's place in the global order was being radically redefined. These conjunctures point to the importance of a self reflexive grounding of our intellectual projects socially and historically. In other words, we need to acknowledge that our 'conversation' is always embedded in wider structures of power and that not everyone has equal access to it.

\section{For a truly cosmopolitan anthropology}

A cosmopolitan anthropology needs to take as its subject of enquiry those processes through which the intellectual trajectory of cosmopolitanism as a notion is shaped and moulded. It needs to ask how and where cosmopolitan spaces are created and produced; who has access to them and whose voices are excluded; and finally` how and what makes it possible and attractive to whom to identify with and engage in cosmopolitan practices. The cosmopolitan, as I have argued, is socially produced; this goes as much for anthropology and anthropologists as for anyone else. As feminist scholars have asserted, the power to produce authoritative knowledge - knowledge that counts - is not equally open to all. A truly cosmopolitan anthropology would need to go beyond its Anglosaxon male canon in order to accommodate, acknowledge and welcome a more diverse constituency of interlocutors in its conversation so as to broaden the base for our knowledge production. Coronil provides a helpful suggestion:

[W]hile theory formation is often a transcultural process, the canonization of theory is fundamentally a power-laden metropolitan operation that, through silencing and selective appropriation, conceals the complicity between knowledge and power.... 
The recognition of the existence of a dynamic exchange between dominant and subaltern knowledge may enable us to move beyond canonical social sciences toward "transcultural social sciences" - that is, social sciences open to their own decolonization through worldwide transactions between centers and borders, the dominant and the subaltern $(2005: 148)$.

Kuper finishes his article with a plea for a cosmopolitan project for anthropology, which 'cannot be bound in the service of any political programme' (1994:551). A reflexive anthropology is not bound to any particular political programme, but it is inevitably aware of the political nature of its intellectual project. As Stade has commented, Kuper's programme expresses an 'ideological, assertive modernism' (2007:227); it is in itself hardly apolitical. Any discussion of cosmopolitanism necessarily enters into 'a domain of contested politics' (Robbins 1998:12). It was in recognition of this predicament that Robbins and Cheah chose Cosmopolitics as the title of their jointly edited volume. Cosmopolitics, they argue, represents 'one effort to describe, from within multiculturalism, a name for the genuine striving toward common norms and mutual translatability that is also part of multiculturalism' (1998:12-13). Would a cosmopolitan project that did not acknowledge the need for translation across cultural worlds within anthropology itself be worth its name?

\section{References cited}

Ardener, Edwin, and Shirley Ardener

1965 A Directory Study of Social Anthropologists. British Journal of Sociology 16(4):296314.

Beck, Ulrich

2002 The Cosmopolitan Society and its Enemies. Theory Culture \& Society 19(1-2):17-44.

Benítez Rojo, Antonio

1992 The repeating island: the Caribbean and the postmodern perspective. J. E. Maraniss, transl. Durham, N.C ; London: Duke University Press.

Berg, Mette Louise

2009 Between Cosmopolitanism and the National Slot: Cuba's Diasporic Children of the Revolution. Identities: Global Studies in Culture and Power 16(2):129-156.

Bourdieu, Pierre

2003 Participant Objectivation. Journal of the Royal Anthropological Institute 9(2):281294.

Calhoun, Craig 
2003 'Belonging' in the Cosmopolitan Imaginary. Ethnicities 3(4):531-568.

Chomsky, Aviva

2000 'Barbados or Canada?' Race, Immigration, and Nation in Early-Twentieth-Century Cuba. Hispanic American Historical Review 80(3):415-462.

Coronil, Fernando

1995 Introduction to the Duke University Press Edition. Transculturation and the Politics of Theory: Countering the Center, Cuban Counterpoint. In Cuban Counterpoint:

Tobacco and Sugar. F. Ortiz, ed. pp. ix-lvi. Durham: Duke University Press.

2005 Transcultural Anthropology in the Américas (with an Accent): The Uses of Fernando Ortiz. In Cuban Counterpoints: The Legacy of Fernando Ortiz. M. A. Font and A. W. Quiroz, eds. pp. 139-156. Lanham: Lexington Books.

Corsín Jiménez, Alberto

2004 Teaching the Field: The Order, Ordering, and Scale of Knowledge. In Teaching Rites and Wrongs: Universities and the Making of Anthropologists. D. Mills and M. Harris, eds. pp. 145-162. Birmingham: C-SAP.

Font, Mauricio A., and Alfonso W. Quiroz

2005 Cuban counterpoints : the legacy of Fernando Ortiz. Lanham, Md. ; Oxford: Lexington Books.

Gibb, Robert, and David Mills

2001 An interview with Adam Kuper. Social Anthropology 9(2):207-216.

Gupta, Akhil, and James Ferguson

1997 Discipline and Practice: "The Field" as Site, Method, and Location in Anthropology. In Anthropological Locations. Boundaries and Grounds of a Field Science. A. Gupta and J. Ferguson, eds. pp. 1-46. Berkeley: University of California Press.

Hannerz, Ulf

2004 Cosmopolitanism. In A Companion to the Anthropology of Politics. D. Nugent and J. Vincent, eds. pp. 69-85. Oxford: Blackwell Publishing.

Harvey, David

2000 Cosmopolitanism and the banality of geographical evils. Public Culture 12(2):529564.

Kahn, Joel S.

2003 Anthropology as Cosmopolitan Practice? Anthropological Theory 3(4):403-415.

Kuper, Adam

1994 Culture, Identity and the Project of a Cosmopolitan Anthropology. Man (NS) 29(3):118.

Law, Ian, Deborah Phillips, and Laura Turney

2004 Institutional racism in higher education. Stoke on Trent: Trentham Books.

Leach, Edmund R. 
1984 Glimpses of the Unmentionable in the History of British Social Anthropology. Annual Review of Anthropology 13:1-23.

Malinowski, Bronislaw

1995 Introduction. In Cuban Counterpoint: Tobacco and Sugar. F. Ortiz, ed. pp. lvii-lxiv. Durham: Duke University Press.

Mills, David, and Mette Louise Berg

forthcoming Gender, Disembodiment and Vocation: Exploring the Unmentionables of British Academic Life. Critique of Anthropology.

Mintz, Sidney W.

1996 Enduring Substances, Trying Theories: The Caribbean Region as Oikoumenê. JRAI 2(2):289-311.

Noble, Greg

2009 Everyday Cosmopolitanism and the Labour of Intercultural Community. In Everyday Multiculturalism. A. Wise and S. Velayutham, eds. pp. 46-65. Basingstoke: Palgrave Macmillan.

Nussbaum, Martha

1994 Patriotism and Cosmopolitanism. The Boston Review XIX(5).

Ortiz, Fernando

1940 Contrapunteo cubano del tabaco y el azúcar: Advertencia de sus contrastes agrarios, económicos, históricos y sociales, su etnografía y su transculturación. Havana: Jesús Montero.

1995 Cuban counterpoint : tobacco and sugar. H. De Onís, transl. Durham, N.C ; London: Duke University Press.

Pérez Firmat, Gustavo

1989 The Cuban condition : translation and identity in modern Cuban literature. Cambridge: Cambridge University Press.

Rabinow, Paul

1986 Representations are social facts: modernity and post-modernity in anthropology. In Writing culture: The poetics and politics of ethnography. J. Clifford and G. E. Marcus, eds. pp. 234-261. Berkeley: University of California Press.

Robbins, Bruce

1998 Introduction Part I: Actually Existing Cosmopolitanism. In Cosmopolitics: Thinking and Feeling Beyond the Nation. P. Cheah and B. Robbins, eds. pp. 1-19. Minneapolis: University of Minnesota Press.

Stade, Ronald

2007 Cosmopolitans and Cosmopolitanism in Anthropology. Social Anthropology 15(2):226-229.

Trouillot, Michel-Rolph 
1992 The Caribbean Region: An Open Frontier in Anthropological Theory. Annual Review of Anthropology 21:19-42.

Vertovec, Steven, and Susanne Wessendorf eds.

2010 The Multiculturalism Backlash: European Discourses, Policies and Practices. London: Routledge.

Wardle, Huon

2000 An Ethnography of Cosmopolitanism in Kingston, Jamaica. Lewiston: The Edwin Mellen Press.

Werbner, Pnina

2008 Introduction: Towards a New Cosmopolitan Anthropology. In Anthropology and the New Cosmopolitanism. P. Werbner, ed. pp. 1-29. Oxford: Berg. 